\title{
Paracoccus stylophorae sp. nov., isolated from the reef-building coral Stylophora pistillata
}

Correspondence
Wen-Ming Chen
p62365@ms28.hinet.net

\author{
Shih-Yi Sheu, ${ }^{1}$ Sing-Rong Jiang, ${ }^{2}$ Chaolun Allen Chen, ${ }^{3}$ Jih-Terng Wang ${ }^{4}$ \\ and Wen-Ming Chen ${ }^{2}$
}

\author{
${ }^{1}$ Department of Marine Biotechnology, National Kaohsiung Marine University, No. 142, Hai-Chuan \\ Rd, Nan-Tzu, Kaohsiung City 811, Taiwan \\ ${ }^{2}$ Laboratory of Microbiology, Department of Seafood Science, National Kaohsiung Marine \\ University, No. 142, Hai-Chuan Rd, Nan-Tzu, Kaohsiung City 811, Taiwan \\ ${ }^{3}$ Research Center for Biodiversity, Academia Sinica, Nangang 115, Taipei, Taiwan \\ ${ }^{4}$ Institute of Biotechnology, Tajen University, Yanpu, Pingtung 907, Taiwan
}

\begin{abstract}
A bacterial strain, designated $\mathrm{KTW}-16^{\top}$, was isolated from the reef-building coral Stylophora pistillata, collected from southern Taiwan. Strain $\mathrm{KTW}-16^{\top}$ was a Gram-negative, facultatively anaerobic, pale-yellow, non-motile short rod. Phylogenetic analysis based on 16S rRNA gene sequences showed that strain $\mathrm{KTW}-16^{\top}$ belonged to the genus Paracoccus in the

Alphaproteobacteria and exhibited 93.7-96.9\% 16S rRNA gene sequence similarity with type strains of species of the genus Paracoccus ( $96.9 \%$ with Paracoccus alcaliphilus JCM $7364^{\top}$ ). Strain $\mathrm{KTW}-16^{\mathrm{T}}$ grew at $15-40{ }^{\circ} \mathrm{C}$ (optimum $35^{\circ} \mathrm{C}$ ), at $\mathrm{pH} 6.0-10.0$ (optimum $\mathrm{pH} 8.0$ ) and with $0-9 \% \mathrm{NaCl}$ (optimum $5 \%$ ). The predominant cellular fatty acids were $\mathrm{C}_{18: 1} \omega 7 \mathrm{c}, \mathrm{C}_{19: 0}$ cyclo $\omega 8 \mathrm{c}$ and $\mathrm{C}_{18: 0}$. The major respiratory quinone was $\mathrm{Q}-10$ and the DNA $\mathrm{G}+\mathrm{C}$ content was $69.1 \mathrm{~mol} \%$. The polar lipid profile consisted of phosphatidylglycerol, diphosphatidylglycerol, phosphatidylcholine and several unknown polar lipids. The physiological and biochemical tests allowed clear phenotypic differentiation of the isolate from the type strains of already described Paracoccus species. It is evident from the genotypic, phenotypic and chemotaxonomic analysis that strain KTW $-16^{\top}$ should be classified in a novel species of the genus Paracoccus, for which the name Paracoccus stylophorae sp. nov. is proposed. The type strain is KTW-16 ${ }^{\top}$ (=LMG

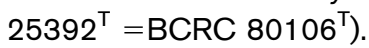

The genus Paracoccus, first proposed by Davis et al. (1969), belongs to the family Rhodobacteraceae of the order Rhodobacterales in the Alphaproteobacteria. At the time of writing, the genus Paracoccus comprises 30 recognized species. Members of the genus Paracoccus are Gramnegative and oxidase- and catalase-positive and have a high metabolic versatility, a large amount of $\mathrm{C}_{18: 1} \omega 7 c$ and Q-10 as the predominant respiratory quinone. Members of this genus have been isolated from soil (Siller et al., 1996; Tsubokura et al., 1999), bioreactors (La et al., 2005), activated sludge (Liu et al., 2006), root nodules (Deng et al., 2011), cornetfish (Kim et al., 2010) and the marine environment (Berry et al., 2003; Kim et al., 2006; Liu et al., 2008; Chen et al., 2011), indicating that members of the genus Paracoccus may exist in various environments. At least one species has been identified as an occasional

The GenBank/EMBL/DDBJ accession number for the $16 \mathrm{~S}$ rRNA gene sequence of strain KTW-16 ${ }^{\top}$ is GQ281379.

A supplementary figure and a supplementary table are available with the online version of this paper. pathogen of humans (Daneshvar et al., 2003; Wallet et al., 2010). The aim of the present study was to determine the taxonomic position of a Paracoccus-like strain, designated KTW-16 ${ }^{\mathrm{T}}$, isolated from the reef-building coral Stylophora pistillata, collected off the coast of southern Taiwan.

A coral sample (50 g) was collected in a sterile bag at a depth of 3-8 $\mathrm{m}$ from the Kenting coast, Pingtung County, southern Taiwan ( $\left.21^{\circ} 52^{\prime} 35^{\prime \prime} \mathrm{N} 120^{\circ} 43^{\prime} 29^{\prime \prime} \mathrm{E}\right)$, stored at $4{ }^{\circ} \mathrm{C}$ and transported to the laboratory within 3-4 h. The coral sample was ground to powder and plated on marine agar 2216 (MA; BD Difco) using the standard dilutionplating method. After incubation at $25{ }^{\circ} \mathrm{C}$ for 5 days, strain KTW $-16^{\mathrm{T}}$ was purified from a single colony. The strain was preserved at $-80{ }^{\circ} \mathrm{C}$ as a $20 \%(\mathrm{v} / \mathrm{v})$ glycerol suspension in marine broth 2216 (MB; BD Difco) or by lyophilization with $20 \%(\mathrm{w} / \mathrm{v})$ skimmed milk. The most closely related type strain, Paracoccus alcaliphilus JCM $7364^{\mathrm{T}}$, was obtained from the Japan Collection of Microorganisms and used as a reference strain for phenotypic and genotypic tests. 
Morphology of cells from lag, exponential and stationary phase was observed by phase-contrast microscopy (DM 2000; Leica). The motility of cells was tested by the hanging drop and semi-solid agar methods. The Spot Test flagella stain (BD Difco) was used for flagellum staining. The Gram stain set $\mathrm{S}$ kit (BD Difco) and the Ryu non-staining $\mathrm{KOH}$ method (Powers, 1995) were adopted for testing the Gram reaction. Poly- $\beta$-hydroxybutyrate granule accumulation was observed under light microscopy after staining with Sudan black. Colony morphology was examined using a stereoscopic microscope (SMZ 800; Nikon). The pH range for growth (at intervals of $1 \mathrm{pH}$ unit) was examined in $\mathrm{MB}$ using biological buffers as follows: glycine $/ \mathrm{HCl}, \mathrm{pH} 3.0$ 4.0; citrate $/ \mathrm{Na}_{2} \mathrm{HPO}_{4}, \mathrm{pH} 4.0-6.0$; phosphate buffer, $\mathrm{pH}$ 6.0-8.0; and glycine/NaOH, pH 9.0-12.0. The $\mathrm{pH}$ was adjusted prior to sterilization and post-sterilization controls revealed only minor changes in $\mathrm{pH}$. Growth with $0,0.5$ and $1.0-15.0 \%(\mathrm{w} / \mathrm{v}) \mathrm{NaCl}$ (in increments of $1.0 \%$ $\mathrm{NaCl}$ ) was tested in $\mathrm{NaCl}$-free $\mathrm{MB}$ prepared according to the formula of the medium except that the $\mathrm{NaCl}$ concentration was altered as required. Growth at $4-45{ }^{\circ} \mathrm{C}$ was measured in $\mathrm{MB}$. Cellular growth was determined by measuring the $\mathrm{OD}_{600}$ of cultures. Anaerobic cultivation was performed on MA using the Oxoid AnaeroGen system.

Genomic DNA was isolated using a kit and the 16S rRNA gene sequence was analysed as described previously (Chen et al., 2001). In brief, primers FD1 (5'-AGAGTTTGATCCTGGCTCAG-3') and RD1 (5'-CAGGCCTAACACATGCAA GTC-3') were used for PCR amplification. These primers correspond to nucleotide positions 8-27 and 1524-1540, respectively, of the Escherichia coli 16S rRNA gene and can be used to amplify nearly full-length sequences of the 16S rRNA gene. After purification of the PCR products, direct sequencing was performed using sequencing primers FD1, RD1, 520F and 800R (Anzai et al., 1997) and an automated DNA sequencer (ABI Prism 3730; Applied Biosystems). An almost-complete 16S rRNA gene sequence (1401 nt) of strain KTW-16 ${ }^{\mathrm{T}}$ was compared against sequences available from the EzTaxon server (Chun et al., 2007), the Ribosomal Database Project (Maidak et al., 2001) and the GenBank database (http:// www.ncbi.nlm.nih.gov/BLAST/). Sequence analysis was performed using BioEdit (Hall, 1999) and MEGA version 3.1 (Kumar et al., 2004) after multiple alignment of the data by CLUSTAL X (Thompson et al., 1997). Distances (corrected according to Kimura's two-parameter model; Kimura, 1983) were calculated and clustering was performed using the neighbour-joining method (Saitou \& Nei, 1987). Maximum-likelihood (Felsenstein, 1981) and maximumparsimony (Kluge \& Farris, 1969) trees were generated using the treeing algorithms contained in the PHYLIP software package (Felsenstein, 1993). In each case, bootstrap values were calculated on the basis of 1000 replications. A comparison of the 16S rRNA gene sequence of strain KTW- $16^{\mathrm{T}}$ with those of members of the order Rhodobacterales in the Alphaproteobacteria showed that the strain fell within the evolutionary radiation occupied by the genus Paracoccus. In the neighbour-joining phylogenetic tree, strain KTW $-16^{\mathrm{T}}$ formed a separate lineage within the genus Paracoccus and similar topologies were obtained in phylogenetic trees generated using the maximumparsimony and maximum-likelihood algorithms (Fig. 1). According to the pairwise sequence comparisons, strain KTW-16 ${ }^{\mathrm{T}}$ exhibited 93.7-96.9\% 16S rRNA gene sequence similarity with type strains of species of the genus Paracoccus. Strain KTW $-16^{\mathrm{T}}$ was closely related to P. alcaliphilus JCM $7364^{\mathrm{T}}(96.9 \%$ 16S rRNA gene sequence similarity), Paracoccus homiensis DD-R $11^{\mathrm{T}} \quad(96.5 \%)$, Paracoccus zeaxanthinifaciens ATCC $21588^{\mathrm{T}}(96.2 \%)$ and Paracoccus denitrificans DSM $413^{\mathrm{T}}$ (95.9\%). 16S rRNA gene sequence similarity between strain KTW-16 ${ }^{\mathrm{T}}$ and other members of the order Rhodobacterales was below $96.6 \%$.

The DNA G + C content of strain KTW- $16^{\mathrm{T}}$ was estimated as described by Mesbah et al. (1989). The nucleoside mixture was separated by means of HPLC. The DNA G + C content of strain $\mathrm{KTW}-16^{\mathrm{T}}$ was $69.1 \pm 1.0 \mathrm{~mol} \%$. Isoprenoid quinones were purified by the methods outlined in Minnikin et al. (1984) and analysed by HPLC as described by Collins (1985). The major isoprenoid quinone of strain KTW-16 ${ }^{\mathrm{T}}$ was ubiquinone 10 (Q-10).

Biomass of strain KTW-16 ${ }^{\mathrm{T}}$ and P. alcaliphilus JCM $7364^{\mathrm{T}}$ was obtained after aerobic growth on MA at $30{ }^{\circ} \mathrm{C}$ for 3 days. Fatty acid methyl esters were prepared, separated and identified according to the instructions for the Microbial Identification System (Microbial ID; MIDI) (Sasser, 1990). The predominant fatty acids of strain KTW- $16^{\mathrm{T}}$ were $\mathrm{C}_{18: 1} \omega 7 c(49.4 \%), \mathrm{C}_{19: 0}$ cyclo $\omega 8 c$ $(22.7 \%)$ and $\mathrm{C}_{18: 0}(12.1 \%)$. The fatty acid profile of strain KTW $-16^{\mathrm{T}}$ was similar to those of the type strains of other Paracoccus species, including $P$. alcaliphilus JCM $7364^{\mathrm{T}}, P$. homiensis DD-R $11^{\mathrm{T}}, P$. zeaxanthinifaciens and P. denitrificans DSM $413^{\mathrm{T}}$, although there were differences in the proportions of some components: for example, in strain KTW- $16^{\mathrm{T}}$, the quantities of $\mathrm{C}_{19: 0}$ cyclo $\omega 8 \mathrm{c}$ and $\mathrm{C}_{18: 0}$ were higher and the quantity of $\mathrm{C}_{18: 1} \omega 7 c$ was lower (Table 1).

Polar lipids were extracted and analysed by two-dimensional TLC according to Tindall (1990) and Altenburger et al. (1996). Strain KTW- $16^{\mathrm{T}}$ exhibited a complex polar lipid profile consisting of phosphatidylglycerol (PG), diphosphatidylglycerol (DPG), phosphatidylcholine (PC), an unknown aminolipid (AL1), an unknown glycolipid (GL1) and four unknown phospholipids (PL2-5) (Supplementary Fig. S1, available in IJSEM Online). This profile was very similar to that of $P$. alcaliphilus JCM $7364^{\mathrm{T}}$ : both the isolate and the reference strain contained PG, DPG, PC, AL1, GL1 and PL2-4. However, unknown phospholipid PL1 was absent in strain $\mathrm{KTW}-16^{\mathrm{T}}$ but present in $P$. alcaliphilus JCM $7364^{\mathrm{T}}$ and unknown phospholipid PL5 was present in strain KTW-16 ${ }^{\mathrm{T}}$ but absent in $P$. alcaliphilus JCM $7364^{\mathrm{T}}$. Thus, there were differences as well as similarities in the polar lipid profiles between the isolate and the reference strain. 


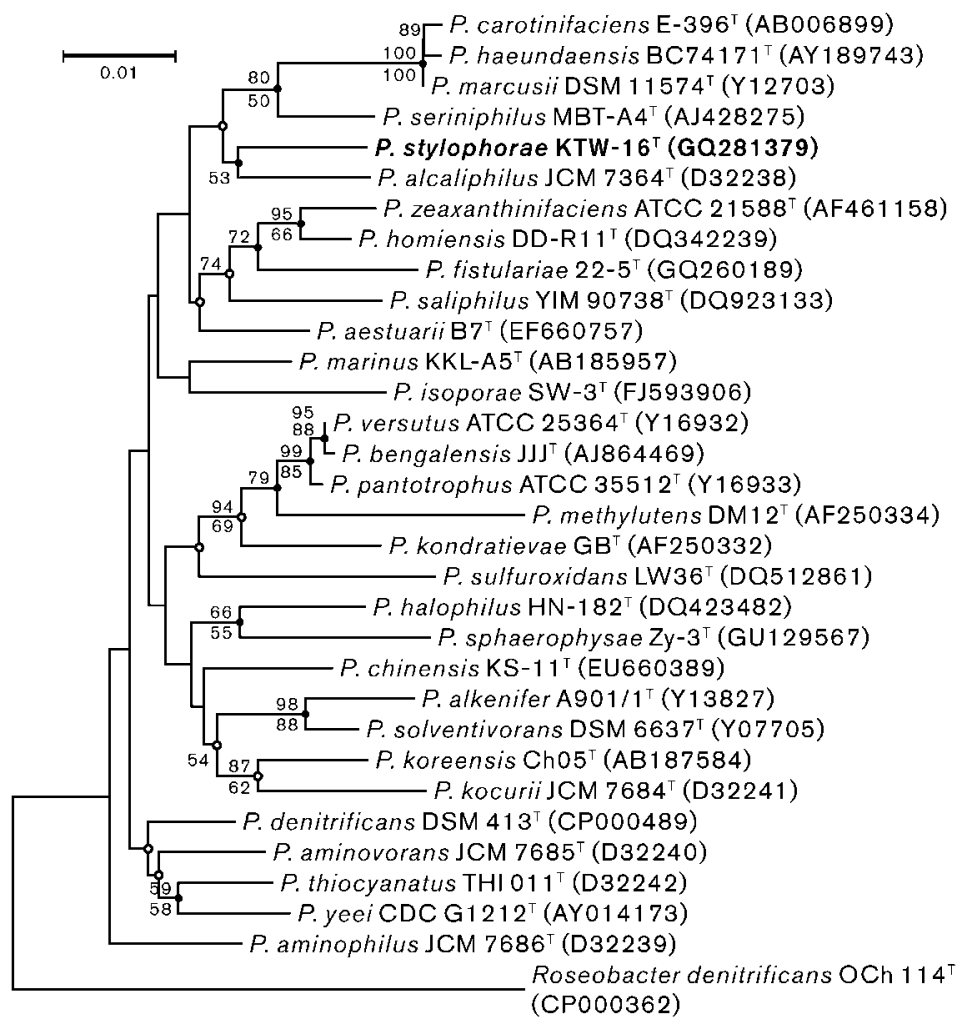

Fig. 1. Neighbour-joining phylogenetic tree based on 16S rRNA gene sequences showing the position of strain KTW-16 ${ }^{\top}$ in the genus Paracoccus. Bootstrap values ( $>50 \%$ ) based on 1000 replications are shown at branch nodes (above, neighbour joining; below, maximum parsimony). Filled circles indicate that the corresponding nodes were also recovered in trees generated using the maximum-likelihood and maximum-parsimony algorithms. Open circles indicate that the corresponding nodes were also recovered in the tree generated with the maximum-parsimony algorithm. Roseobacter denitrificans OCh $114^{\top}$ was used as an outgroup. Bar, 0.01 substitutions per nucleotide position.

Strain KTW-16 ${ }^{\mathrm{T}}$ was examined for a broad range of phenotypic properties. Catalase, oxidase, DNase, lipase and hydrolysis of starch, casein and Tweens 20, 40, 60 and 80 were determined according to standard methods (Gerhardt et al., 1994; MacFaddin, 2000). Hydrolysis of alginate (1\% w/v sodium alginate) was tested on MA (Hosoya et al., 2009). The API 20 NE, API ZYM (bioMérieux) and GN2 MicroPlate (Biolog) systems were used to determine the biochemical properties, enzyme activities and carbohydrate utilization pattern of strain KTW- $16^{\mathrm{T}}$. API ZYM tests were performed according to the manufacturer's recommendation and were read after $4 \mathrm{~h}$ at $37^{\circ} \mathrm{C}$. For GN2 MicroPlate and API $20 \mathrm{NE}$ tests, because strain $\mathrm{KTW}-16^{\mathrm{T}}$ required $5 \% \mathrm{NaCl}$ for optimum growth, cells were suspended in artificial seawater (containing $\mathrm{l}^{-1}$ distilled water: $24 \mathrm{~g} \mathrm{NaCl}, 5.1 \mathrm{~g} \mathrm{MgCl}_{2}, 4 \mathrm{~g}$ $\mathrm{Na}_{2} \mathrm{SO}_{4}, 1.1 \mathrm{~g} \mathrm{CaCl}_{2}, 0.7 \mathrm{~g} \mathrm{KCl}, 0.2 \mathrm{~g} \mathrm{NaHCO}_{3}, 0.1 \mathrm{~g} \mathrm{KBr}$, $0.027 \mathrm{~g} \mathrm{H}_{3} \mathrm{BO}_{3}, 0.024 \mathrm{~g} \mathrm{SrCl}_{2}, 0.003 \mathrm{~g} \mathrm{NaF}$; Lyman \& Fleming, 1940) and results were read after $72 \mathrm{~h}$ at $30{ }^{\circ} \mathrm{C}$.

Sensitivity to antibiotics was by spreading cells $(0.5$ McFarland standard) on MA and placing antibiotic discs on the surface of the agar ( $\mu$ g per disc): ampicillin (10), chloramphenicol (30), gentamicin (10), kanamycin (30), nalidixic acid (30), novobiocin (30), penicillin G (10), rifampicin (5), streptomycin (10) and tetracycline (30). The effects of antibiotics on cell growth were assessed after 3 days at $30{ }^{\circ} \mathrm{C}$. The diameter of each disc was $8 \mathrm{~mm}$ and the strain was considered susceptible if the diameter of the inhibition zone was $>13 \mathrm{~mm}$, partly susceptible at $10-12 \mathrm{~mm}$ and resistant at $<10 \mathrm{~mm}$, as described by Nokhal \& Schlegel (1983).
The physiological, biochemical and morphological characteristics of strain $\mathrm{KTW}-16^{\mathrm{T}}$ are given in the species description, Tables 1 and 2, Supplementary Table S1 and Supplementary Fig. S1. Phenotypic examinations revealed many common traits between the isolate and its closest relatives, $P$. alcaliphilus $\mathrm{JCM} 7364^{\mathrm{T}}, P$. homiensis DD-R $11^{\mathrm{T}}$, $P$. zeaxanthinifaciens $\mathrm{R}-1512^{\mathrm{T}}$ and $P$. denitrificans DSM $413^{\mathrm{T}}$. All strains were Gram-negative, heterotrophic and oxidase- and catalase-positive. They contained large amounts of $\mathrm{C}_{18: 1} \omega 7 c$, the main respiratory quinone was Q-10 and the DNA G+C content was 63-69 mol\%. However, strain KTW- $16^{\mathrm{T}}$ could be differentiated clearly from all of the reference strains by its inability to grow at $10{ }^{\circ} \mathrm{C}$, its ability to assimilate $\mathrm{N}$-acetylglucosamine and maltose (Table 2), some differences in phospholipid components (Supplementary Fig. S1), its ability to utilize 2 -aminoethanol, 2,3-butanediol, $\alpha$-D-glucose 1-phosphate and D-glucose 6-phosphate and its inability to utilize succinic acid monomethyl ester, $\beta$-hydroxybutyric acid, DL-lactic acid and L-proline as sole carbon sources (Supplementary Table S1). Strain KTW- $16^{\mathrm{T}}$ could also be differentiated from each of the reference strains by a number of features: for example, from $P$. alcaliphilus JCM $7364^{\mathrm{T}}$ by hydrolysis of gelatin, aesculin and DNA; from $P$. homiensis $\mathrm{DD}-\mathrm{R} 11^{\mathrm{T}}$ by colony colour, motility, maximum $\mathrm{NaCl}$ concentration for growth, the presence of poly- $\beta$-hydroxybutyrate granules, reduction of nitrate to nitrite, $\beta$-galactosidase and hydrolysis of starch; from P. zeaxanthinifaciens $\mathrm{R}-1512^{\mathrm{T}}$ by colony colour, $\mathrm{NaCl}$ concentration range for growth, reduction of nitrate to 
Table 1. Cellular fatty acid compositions of strain $\mathrm{KTW}-16^{\top}$ and closely related members of the genus Paracoccus

Strains: 1 , Paracoccus stylophorae sp. nov. KTW $-16^{\mathrm{T}} ; 2$, P. alcaliphilus JCM $7364^{\mathrm{T}} ; 3, P$. homiensis $\mathrm{DD}-\mathrm{R} 11^{\mathrm{T}} ; 4, P$. zeaxanthinifaciens $\mathrm{R}-1512^{\mathrm{T}} ; 5, P$. denitrificans DSM $413^{\mathrm{T}}$. Data in columns 1 and 2 were obtained in this study and those in columns 3-5 were taken from Chen et al. (2011). All strains were grown on MA at $30{ }^{\circ} \mathrm{C}$ for 3 days. Values are percentages of total fatty acids; fatty acids that made up $<1 \%$ of the total in all strains are not shown.

\begin{tabular}{|c|c|c|c|c|c|}
\hline Fatty acid & 1 & 2 & 3 & 4 & 5 \\
\hline $\mathrm{C}_{10: 0} 3-\mathrm{OH}$ & 2.0 & 4.4 & 4.1 & 7.8 & 4.3 \\
\hline $\mathrm{C}_{11: 0} 2-\mathrm{OH}$ & - & - & - & - & 1.1 \\
\hline anteiso- $\mathrm{C}_{12: 0}$ & - & - & - & - & 3.2 \\
\hline anteiso- $\mathrm{C}_{13: 0}$ & - & - & - & - & 1.5 \\
\hline$C_{16: 0}$ & 1.8 & 1.7 & - & 2.1 & 16.2 \\
\hline iso- $\mathrm{C}_{17: 0} 3-\mathrm{OH}$ & - & 1.1 & - & - & - \\
\hline $\mathrm{C}_{18: 0}$ & 12.1 & 8.3 & 4.4 & 6.0 & 4.9 \\
\hline $\mathrm{C}_{18: 0} 3-\mathrm{OH}$ & 1.0 & - & - & 1.9 & - \\
\hline $\mathrm{C}_{18: 1} \omega 7 c$ & 49.4 & 70.9 & 80.4 & 72.8 & 57.1 \\
\hline $\mathrm{C}_{18: 1} \omega 9 c$ & - & - & - & - & 1.4 \\
\hline 11-Methyl $\mathrm{C}_{18: 1} \omega 7 c$ & 5.2 & 1.0 & 5.1 & - & - \\
\hline $\mathrm{C}_{19: 0}$ cyclo $\omega 8 \mathrm{c}$ & 22.7 & 5.4 & - & - & - \\
\hline \multicolumn{6}{|l|}{ Summed features ${ }^{*}$} \\
\hline 2 & 2.0 & 4.6 & 1.7 & 5.4 & 3.6 \\
\hline 3 & - & - & - & 2.8 & 1.2 \\
\hline
\end{tabular}

${ }^{*}$ Summed features represent groups of two or three fatty acids that cannot be separated by GLC using the Microbial Identification System. Summed feature 2 consisted of $\mathrm{C}_{14: 0} 3-\mathrm{OH}$ and/or iso- $\mathrm{C}_{16: 1}$ I. Summed feature 3 consisted of $\mathrm{C}_{16: 1} \omega 7 c$ and/or $\mathrm{C}_{16: 1} \omega 6 c$.

nitrite, $\beta$-galactosidase and hydrolysis of gelatin, urea and Tweens 20 and 80; and from P. denitrificans DSM $413^{\mathrm{T}}$ by colony colour, maximum $\mathrm{NaCl}$ concentration for growth, reduction of nitrate to nitrite and nitrite to nitrogen and hydrolysis of gelatin, aesculin and urea.

Strain KTW-16 ${ }^{\mathrm{T}}$ was halophilic and could reduce nitrate. Most members of the genus Paracoccus are not halophilic and cannot reduce nitrate. Only ten species are halophilic, Paracoccus haeundaensis, P. seriniphilus, P. fistulariae, P. halophilus, P. zeaxanthinifaciens, P. homiensis, P. saliphilus, $P$. aestuarii, $P$. marinus and $P$. isoporae, and, of these, only the first three can reduce nitrate. Colony colour distinguished strain KTW- $16^{\mathrm{T}}$ from $P$. haeundaensis and P. seriniphilus; colonies of strain KTW $-16^{\mathrm{T}}$ were pale yellow whereas $P$. haeundaensis and $P$. seriniphilus form orangered and creamy white colonies, respectively. Strain KTW$16^{\mathrm{T}}$ could be distinguished from $P$. fistulariae by several phenotypic features, such as the ability to hydrolyse Tweens 20, 40, 60 and 80, the presence of esterase lipase (C8) and the absence of esterase (C4), naphthol-AS-BIphosphohydrolase and $\alpha$-glucosidase. Therefore, strain KTW $-16^{\mathrm{T}}$ is a member of the genus Paracoccus but can be separated from other members of the genus by some phenotypic differences.
Table 2. Differential characteristics of strain $\mathrm{KTW}-16^{\top}$ and closely related members of the genus Paracoccus

Strains: 1 , Paracoccus stylophorae sp. nov. KTW-16 ${ }^{\mathrm{T}} ; 2$, P. alcaliphilus JCM $7364^{\mathrm{T}} ; 3, P$. homiensis DD-R $11^{\mathrm{T}} ; 4, \quad$. zeaxanthinifaciens $\mathrm{R}-1512^{\mathrm{T}}$; 5, P. denitrificans DSM $413^{\mathrm{T}}$. Data in columns 1 and 2 were obtained in this study, unless stated otherwise; those in columns 3-5 were taken from Chen et al. (2011). All strains are Gram-negative and oxidase- and catalase-positive. PHB, Poly- $\beta$-hydroxybutyrate.

\begin{tabular}{|lccccc|}
\hline Characteristic & $\mathbf{1}$ & $\mathbf{2}$ & $\mathbf{3}$ & $\mathbf{4}$ & $\mathbf{5}$ \\
\hline Colony colour & PY & PY & DY & DO & CW \\
Motility & - & - & + & - & - \\
Growth at/with: & & & & & \\
$\quad$ NaCl (\%, w/v) & $0-9$ & $0-8$ & $0-14$ & $3-8$ & $0-7$ \\
pH & $6-10$ & $6-10$ & $5-9$ & $6-9$ & $6-8$ \\
Temperature $\left({ }^{\circ} \mathrm{C}\right)$ & $15-40$ & $10-40$ & $10-40$ & $10-40$ & $10-40$ \\
PHB accumulation & + & + & - & + & + \\
Reduction of nitrate to: & & & & & \\
Nitrite & + & + & - & - & - \\
N 2 & - & - & - & - & + \\
$\beta$-Galactosidase & - & - & + & + & - \\
Hydrolysis of: & & & & & \\
Gelatin & + & - & + & - & - \\
Aesculin & + & - & + & + & - \\
Urea & - & - & - & + & + \\
Tweens 20 and 80 & - & - & - & + & - \\
Starch & - & - & + & - & - \\
DNA & + & - & + & + & + \\
Assimilation of: & & & & & \\
Glucose & + & + & - & - & - \\
Arabinose & + & + & - & - & - \\
Mannose & + & + & - & - & - \\
Mannitol & + & + & - & - & - \\
$\quad N-$ Acetylglucosamine & + & - & - & - & - \\
Maltose & + & - & - & - & - \\
Malate & + & + & - & - & - \\
DNA G+C content & 69.1 & $64.4 \dagger$ & 63.0 & 67.6 & 66.5 \\
(mol\%) & & & & & \\
\hline
\end{tabular}

${ }^{*} \mathrm{CW}$, Creamy white; DO, deep orange; DY, deep yellow; PY, pale yellow. $\dagger$ Data from Urakami et al. (1989).

On the basis of $16 \mathrm{~S}$ rRNA gene sequence comparisons, strain $\mathrm{KTW}-16^{\mathrm{T}}$ occupies a distinct position within the genus Paracoccus. This phylogenetic insight is supported by the unique combination of chemotaxonomic characteristics and biochemical traits of the isolate (Tables 1 and 2). Therefore, it is clear from the phylogenetic and phenotypic data that strain KTW $-16^{\mathrm{T}}$ constitutes a novel member of the genus Paracoccus. The name Paracoccus stylophorae sp. nov. is proposed for this taxon.

\section{Description of Paracoccus stylophorae sp. nov.}

Paracoccus stylophorae (sty.lo.pho'ra.e. N.L. gen. n. stylophorae of Stylophora, referring to the isolation of the type strain from a coral belonging to the genus Stylophora). 
Cells are Gram-negative, facultatively anaerobic, short rods (0.9-1.0 $\mu \mathrm{m}$ wide and 1.0-1.2 $\mu \mathrm{m}$ long) and are non-motile. Colonies on MA are pale yellow, circular and convex with entire edges, $0.4-0.5 \mathrm{~mm}$ in diameter on $\mathrm{MA}$ after $24 \mathrm{~h}$ incubation at $30{ }^{\circ} \mathrm{C}$. Growth occurs at $15-40{ }^{\circ} \mathrm{C}$, with $0-9 \%$ $\mathrm{NaCl}$ and at $\mathrm{pH}$ 6.0-10.0. Optimum growth occurs at $35^{\circ} \mathrm{C}$, with $5 \% \mathrm{NaCl}$ and at $\mathrm{pH}$ 8.0. Poly- $\beta$-hydroxybutyrate granule accumulation is observed. Positive for oxidase, catalase and DNase activities. Negative for lipase (corn oil) activity and hydrolysis of casein, starch, alginate and Tweens 20, 40, 60 and 80. With API $20 \mathrm{NE}$, positive for reduction of nitrate, hydrolysis of aesculin and gelatin and assimilation of glucose, arabinose, mannose, mannitol, $\mathrm{N}$-acetylglucosamine, maltose, gluconate, malate, citrate and phenylacetate, but negative for production of indole, fermentation of D-glucose, arginine dihydrolase, urease and $\beta$-galactosidase and assimilation of caprate and adipate. With API ZYM, positive for alkaline phosphatase, esterase lipase (C8), leucine arylamidase and acid phosphatase, but negative for esterase (C4), lipase (C14), valine arylamidase, cystine arylamidase, trypsin, $\alpha$-chymotrypsin, naphthol-AS-BI-phosphohydrolase, $\alpha$ - and $\beta$-galactosidase, $\beta$-glucuronidase, $\alpha$ - and $\beta$-glucosidase, $N$-acetyl- $\beta$ glucosaminidase, $\alpha$-mannosidase and $\alpha$-fucosidase. With GN2 MicroPlates, utilizes Tweens 40 and 80, D-galactonic acid lactone, L-histidine, urocanic acid, 2-aminoethanol, 2,3butanediol, glycerol, DL- $\alpha$-glycerol phosphate, $\alpha$-D-glucose 1phosphate and D-glucose 6-phosphate; all other substrates included in the Biolog GN2 MicroPlate are not utilized. Sensitive to rifampicin, nalidixic acid, kanamycin, chloramphenicol, gentamicin, novobiocin, tetracycline, ampicillin and penicillin G, but resistant to streptomycin. The predominant cellular fatty acids are $\mathrm{C}_{18: 1} \omega 7 c, \mathrm{C}_{19: 0}$ cyclo $\omega 8 c$ and $\mathrm{C}_{18: 0}$. The major respiratory quinone is $\mathrm{Q}-10$. The polar lipids are phosphatidylglycerol, diphosphatidylglycerol, phosphatidylcholine, an unknown aminolipid, an unknown glycolipid and four unknown phospholipids. The DNA G + C content of the type strain is $69.1 \mathrm{~mol} \%$.

The type strain, KTW $-16^{\mathrm{T}}\left(=\mathrm{LMG} 25392^{\mathrm{T}}=\mathrm{BCRC} 80106^{\mathrm{T}}\right)$, was isolated from the reef-building coral Stylophora pistillata, collected off the coast of southern Taiwan.

\section{Acknowledgements}

This study was funded by grants from the Academia Sinica (thematic grant 20082010), Taipei, Taiwan, Republic of China.

\section{References}

Altenburger, P., Kämpfer, P., Makristathis, A., Lubitz, W. \& Busse, H.-J. (1996). Classification of bacteria isolated from a medieval wall painting. J Biotechnol 47, 39-52.

Anzai, Y., Kudo, Y. \& Oyaizu, H. (1997). The phylogeny of the genera Chryseomonas, Flavimonas, and Pseudomonas supports synonymy of these three genera. Int J Syst Bacteriol 47, 249-251.

Berry, A., Janssens, D., Hümbelin, M., Jore, J. P. M., Hoste, B., Cleenwerck, I., Vancanneyt, M., Bretzel, W., Mayer, A. F. \& other authors (2003). Paracoccus zeaxanthinifaciens sp. nov., a zeaxanthinproducing bacterium. Int J Syst Evol Microbiol 53, 231-238.
Chen, W. M., Laevens, S., Lee, T. M., Coenye, T., De Vos, P., Mergeay, M. \& Vandamme, P. (2001). Ralstonia taiwanensis sp. nov., isolated from root nodules of Mimosa species and sputum of a cystic fibrosis patient. Int J Syst Evol Microbiol 51, 1729-1735.

Chen, M.-H., Sheu, S.-Y., Chen, C. A., Wang, J.-T. \& Chen, W.-M. (2011). Paracoccus isoporae sp. nov., isolated from the reef-building coral Isopora palifera. Int J Syst Evol Microbiol 61, 1138-1143.

Chun, J., Lee, J.-H., Jung, Y., Kim, M., Kim, S., Kim, B. K. \& Lim, Y.-W. (2007). EzTaxon: a web-based tool for the identification of prokaryotes based on $16 \mathrm{~S}$ ribosomal RNA gene sequences. Int J Syst Evol Microbiol 57, 2259-2261.

Collins, M. D. (1985). Analysis of isoprenoid quinones. Methods Microbiol 18, 329-366.

Daneshvar, M. I., Hollis, D. G., Weyant, R. S., Steigerwalt, A. G., Whitney, A. M., Douglas, M. P., Macgregor, J. P., Jordan, J. G., Mayer, L. W. \& other authors (2003). Paracoccus yeeii sp. nov. (formerly CDC group EO-2), a novel bacterial species associated with human infection. J Clin Microbiol 41, 1289-1294.

Davis, D. H., Doudoroff, M., Stanier, R. Y. \& Mandel, M. (1969). Proposal to reject the genus Hydrogenomonas: taxonomic implications. Int J Syst Bacteriol 19, 375-390.

Deng, Z.-S., Zhao, L.-F., Xu, L., Kong, Z.-Y., Zhao, P., Qin, W., Chang, J.-L. \& Wei, G.-H. (2011). Paracoccus sphaerophysae sp. nov., a siderophore-producing, endophytic bacterium isolated from root nodules of Sphaerophysa salsula. Int J Syst Evol Microbiol 61, 665-669.

Felsenstein, J. (1981). Evolutionary trees from DNA sequences: a maximum likelihood approach. J Mol Evol 17, 368-376.

Felsenstein, J. (1993). PHYLIP (phylogeny inference package), version 3.5c. Distributed by the author. Department of Genome Sciences, University of Washington, Seattle, USA.

Gerhardt, P., Murray, R. G. E., Wood, W. A. \& Krieg, N. R. (editors) (1994). Methods for General and Molecular Bacteriology. Washington, DC: American Society for Microbiology.

Hall, T. A. (1999). BioEdit: a user-friendly biological sequence alignment editor and analysis program for Windows 95/98/NT. Nucleic Acids Symp Ser 41, 95-98.

Hosoya, S., Adachi, K. \& Kasai, H. (2009). Thalassomonas actiniarum sp. nov. and Thalassomonas haliotis sp. nov., isolated from marine animals. Int J Syst Evol Microbiol 59, 686-690.

Kim, B.-Y., Weon, H.-Y., Yoo, S.-H., Kwon, S.-W., Cho, Y.-H., Stackebrandt, E. \& Go, S.-J. (2006). Paracoccus homiensis sp. nov., isolated from a sea-sand sample. Int J Syst Evol Microbiol 56, 2387-2390.

Kim, Y.-O., Kong, H. J., Park, S., Kang, S.-J., Kim, K.-K., Moon, D. Y., Oh, T.-K. \& Yoon, J.-H. (2010). Paracoccus fistulariae sp. nov., a lipolytic bacterium isolated from bluespotted cornetfish Fistularia commeronii. Int J Syst Evol Microbiol 60, 2908-2912.

Kimura, M. (1983). The Neutral Theory of Molecular Evolution. Cambridge: Cambridge University Press.

Kluge, A. G. \& Farris, F. S. (1969). Quantitative phyletics and the evolution of anurans. Syst Zool 18, 1-32.

Kumar, S., Tamura, K. \& Nei, M. (2004). MEGA3: integrated software for molecular evolutionary genetics analysis and sequence alignment. Brief Bioinform 5, 150-163.

La, H.-J., Im, W.-T., Ten, L. N., Kang, M. S., Shin, D.-Y. \& Lee, S.-T. (2005). Paracoccus koreensis sp. nov., isolated from anaerobic granules in an upflow anaerobic sludge blanket (UASB) reactor. Int J Syst Evol Microbiol 55, 1657-1660.

Liu, X.-Y., Wang, B.-J., Jiang, C.-Y. \& Liu, S.-J. (2006). Paracoccus sulfuroxidans sp. nov., a sulfur oxidizer from activated sludge. Int $J$ Syst Evol Microbiol 56, 2693-2695. 
Liu, Z.-P., Wang, B.-J., Liu, X.-Y., Dai, X., Liu, Y.-H. \& Liu, S.-J. (2008). Paracoccus halophilus sp. nov., isolated from marine sediment of the South China Sea, China, and emended description of genus Paracoccus Davis 1969. Int J Syst Evol Microbiol 58, 257-261.

Lyman, J. \& Fleming, R. H. (1940). Composition of sea water. J Mar Res 3, 134-146.

MacFaddin, J. F. (2000). Biochemical Tests for the Identification of Medical Bacteria, 3rd edn. Baltimore: Williams \& Wilkins.

Maidak, B. L., Cole, J. R., Lilburn, T. G., Parker, C. T., Jr, Saxman, P. R., Farris, R. J., Garrity, G. M., Olsen, G. J., Schmidt, T. M. \& Tiedje, J. M. (2001). The RDP-II (Ribosomal Database Project). Nucleic Acids Res 29, 173-174.

Mesbah, M., Premachandran, U. \& Whitman, W. B. (1989). Precise measurement of the $\mathrm{G}+\mathrm{C}$ content of deoxyribonucleic acid by highperformance liquid chromatography. Int J Syst Bacteriol 39, 159-167.

Minnikin, D. E., O'Donnell, A. G., Goodfellow, M., Alderson, G., Athalye, M., Schaal, K. \& Parlett, J. H. (1984). An integrated procedure for the extraction of bacterial isoprenoid quinones and polar lipids. J Microbiol Methods 2, 233-241.

Nokhal, T. H. \& Schlegel, H. G. (1983). Taxonomic study of Paracoccus denitrificans. Int J Syst Bacteriol 33, 26-37.

Powers, E. M. (1995). Efficacy of the Ryu nonstaining KOH technique for rapidly determining gram reactions of food-borne and waterborne bacteria and yeasts. Appl Environ Microbiol 61, 3756-3758.
Saitou, N. \& Nei, M. (1987). The neighbor-joining method: a new method for reconstructing phylogenetic trees. Mol Biol Evol 4, 406-425.

Sasser, M. (1990). Identification of bacteria by gas chromatography of cellular fatty acids, MIDI Technical Note 101. Newark, DE: MIDI Inc.

Siller, H., Rainey, F. A., Stackebrandt, E. \& Winter, J. (1996). Isolation and characterization of a new Gram-negative, acetone-degrading, nitrate-reducing bacterium from soil, Paracoccus solventivorans sp. nov. Int J Syst Bacteriol 46, 1125-1130.

Thompson, J. D., Gibson, T. J., Plewniak, F., Jeanmougin, F. \& Higgins, D. G. (1997). The CLUSTAL_X windows interface: flexible strategies for multiple sequence alignment aided by quality analysis tools. Nucleic Acids Res 25, 4876-4882.

Tindall, B. J. (1990). Lipid composition of Halobacterium lacusprofundi. FEMS Microbiol Lett 66, 199-202.

Tsubokura, A., Yoneda, H. \& Mizuta, H. (1999). Paracoccus carotinifaciens sp. nov., a new aerobic Gram-negative astaxanthinproducing bacterium. Int J Syst Bacteriol 49, 277-282.

Urakami, T., Tamaoka, J., Suzuki, K. \& Komagata, K. (1989). Paracoccus alcaliphilus sp. nov., an alkaliphilic and facultatively methylotrophic bacterium. Int J Syst Bacteriol 39, 116-121.

Wallet, F., Blondiaux, N., Foy, C. L., Loïez, C., Armand, S., Pagniez, D. \& Courcol, R. J. (2010). Paracoccus yeei: a new unusual opportunistic bacterium in ambulatory peritoneal dialysis. Int J Infect Dis 14, e173e174. 